\title{
Analisis Maturity Level Layanan dan Produktivitas Sumber Daya Manusia berdasarkan Business Goal 15 COBIT 4.1 (Studi Kasus: Dinas Komunikasi dan Informatika Provinsi Jawa Timur)
}

\author{
Cyndya Nandhany ${ }^{*}$, Siti Mukaromah ${ }^{2}$, Arista Pratama ${ }^{3}$ \\ 1,2,3Sistem Informasi/UPN "Veteran" Jawa Timur \\ cyndyaanandhany@gmail.com ${ }^{*}$, sitimukaromah.si@upnjatim.ac.id², \\ aristapratama.si@upnjatim.ac.id ${ }^{3}$
}

\begin{abstract}
Abstrak
Dinas Komunikasi dan Informatika (Diskominfo) Provinsi Jawa Timur merupakan salah satu instansi pemerintah di Provinsi Jawa Timur yang berperan membantu Gubernur Provinsi Jawa Timur dalam menyiapkan bahan yang diperlukan dalam pemerintahan pada bidang komunikasi dan informasi dalam lingkup provinsi Jawa Timur. Penyebarluasan informasi dan pelayanan publik melalui Teknologi Informasi dan Komunikasi (TIK) di Jawa Timur merupakan tugas utama Diskominfo Provinsi Jawa Timur. Berdasarkan data struktural, hasil observasi, dan penelitian terdahulu diperoleh bahwa mayoritas jumlah staf merupakan Aparatur Sipil Negara (ASN) yang berasal dari instansi pemerintah lain sehingga terbatasnya pemahaman terhadap urgensi dan perkembangan $\mathrm{Tl}$, sistem informasi belum sepenuhnya terintegrasi karena minim pemberdayaan sumber daya manusia dan pengembangan sistem membutuhkan pihak ketiga, serta pembagian tugas pokok pegawai belum dibagi secara merata, maka diperlukan analisis maturity level. Penelitian ini bertujuan untuk menganalisis maturity level layanan dan produktivitas sumber daya manusia pada Diskominfo Procinsi Jawa Timur. Pelitian dilaksanakan dengan melakukan observasi, studi literatur, penentuan business goal, pengumpulan data bukti melalui wawancara, penentuan dan analisis maturity level, serta penentuan hasil temuan beserta rekomendasi. Layanan dan produktivitas sumber daya manusia berkaitan erat dengan Business Goal 15 pada perspektif internal COBIT 4.1 tentang meningkatkan dan menjaga produktivitas operasional dan staf. Hasil pengukuran maturity level menunjukan bahwa layanan dan produktivitas sumber daya manusia pada Diskominfo Provinsi Jawa Timur sebesar 3,005477646 yaitu pada level 3 (defined), yang berarti telah didefinisikan kebijakan dan pelaksanaan standarisasi terhadap proses-proses penting seperti arsitektur informasi, infrastruktur TI, pelatihan dan pendidikan pengguna, serta manajemen layanan/insiden, meski belum bersifat formal dan menyeluruh.
\end{abstract}

Kata Kunci: Layanan dan Produktivitas Sumber Daya Manusia, Maturity Level, Cobit 4.1

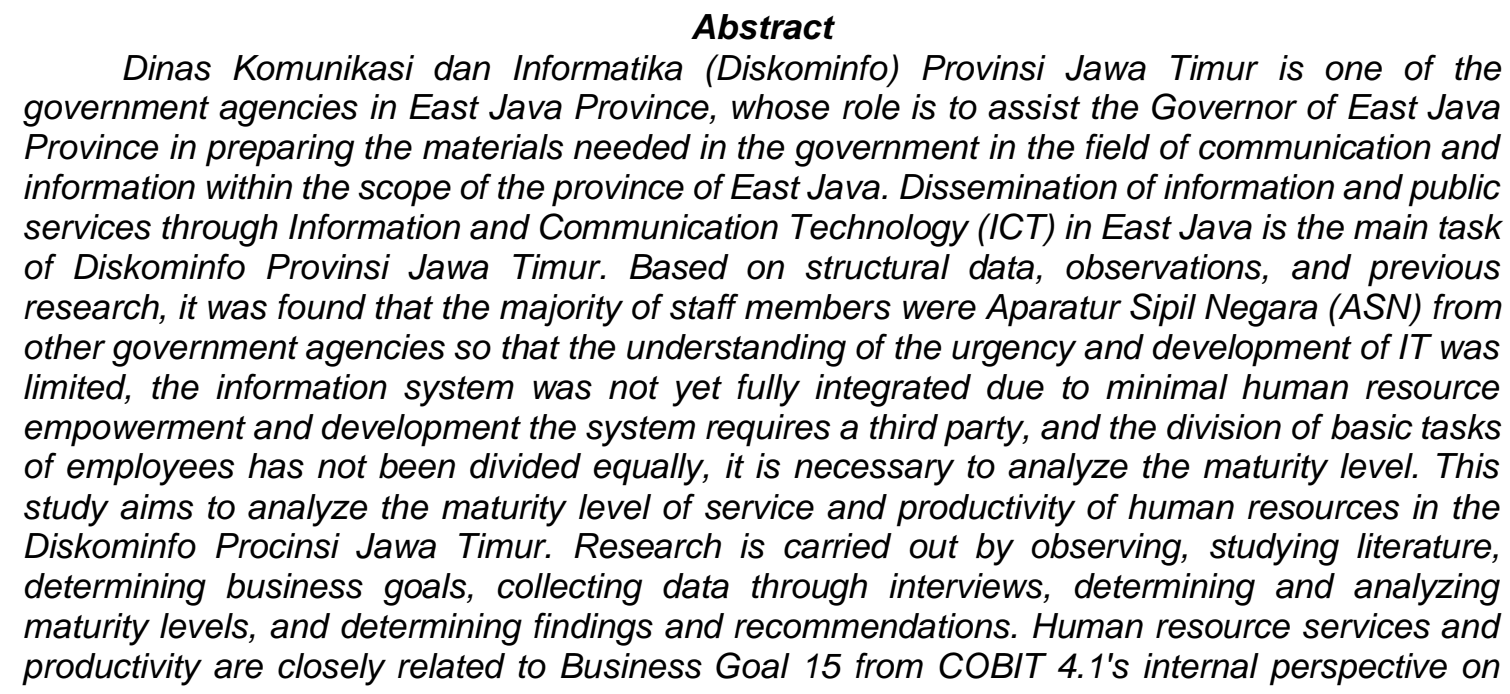


improving and maintaining operational and staff productivity. Maturity level measurement results show that service and productivity of human resources in Diskominfo Provinsi Jawa Timur amounted to 3.005477646, namely at level 3 (defined), which means that policies and implementation of standardization of important processes such as information architecture, IT infrastructure, training and user education, and service / incident management, although not yet formal and comprehensive.

\section{Keywords: Service and Productivity of Human Resources, Maturity Level, Cobit 4.1}

\section{Pendahuluan}

Dinas Komunikasi dan Informatika (Diskominfo) Provinsi Jawa Timur merupakan salah satu instansi pemerintah di Provinsi Jawa Timur yang berperan membantu Gubernur Provinsi Jawa Timur dalam menyiapkan bahan yang diperlukan dalam urusan pemerintahan pada bidang komunikasi dan informasi dalam lingkup provinsi Jawa Timur. Dalam mengelola proses bisnisnya, membutuhkan tata kelola teknologi informasi (IT Governance) untuk memastikan bahwa TI perusahaan mendukung tujuan perusahaan [1].

Data struktural kepemimpinan Diskominfo Provinsi Jawa Timur menyatakan bahwa riwayat pendidikan pegawai mayoritas bukan lulusan sarjana komputer, terlebih para kepala bidang dan kepala seksi yang berhubungan dengan pengelolaan teknologi informasi. Sedangkan, kepala bidang dan kepala seksi sejatinya memiliki peranan penting tentang pemahaman dasar karena memiliki kontrol langsung terhadap pelayanan TI, khususnya Bidang Aplikasi dan Informatika, Infrastruktur TIK, dan Pengelolaan Data dan Statistik, yaitu bidang yang berhubungan langsung dengan implementasi SI/TI [1].

Berdasarkan penelitian terdahulu, mengenai perencanaan strategi sistem informasi Bidang Aptika di Diskominfo Provinsi Jawa Timur, mayoritas staf atau Aparat Sipil Negara (ASN) berasal dari instansi pemerintahan lain, sehingga kemampuan sebagian pegawai dikatakan kurang profesional karena terbatasnya pemahaman terhadap urgensi dan perkembangan SI/TI, pembagian tugas pokok dan fungsi tiap pegawai belum dibagi secara merata, dan sistem informasi belum sepenuhnya terintregrasi karena minimnya pemberdayaan sumber daya manusia/staf, dan membutuhkan pihak ketiga untuk pengembangan sistem [2].

Berdasarkan permasalahan di atas diperlukan pengukuran untuk memperoleh penilaian terkait layanan dalam operasional perusahaan dan produktivitas sumber daya manusia dalam mengahadapi penerapan dan perkembangan TI. Pengukuran dilakukan dengan maturity level, untuk mengidentifikasi, menganalisis, memberikan suatu penilaian, serta memberikan rekomendasi terhadap kinerja internal. Pengukuran membutuhkan framework, agar memperoleh hasil yang valid dan dapat diandalkan [3].

COBIT merupakan kerangka kerja yang disusun oleh Information Technology Governance Institut (ITGI), membahas pengaturan yang mendasari tata kelola melalui pendefinisian strategi dan kontrol [3]. Framework COBIT memiliki beberapa versi dengan fokus berbeda [4]. COBIT 4.1 memiliki keunggulan untuk penyelarasan antara proses bisnis dengan IT berdasarkan pada fokus bisnis, pandangan yang dapat dimengerti manajemen tentang apa yang dikerjakan TI, serta kepemilikan dan tanggung jawab yang jelas pada orientasi proses [5].

Penelitian diawali dengan menentukan perspektif sebagai acuan. Perspektif yang digunakan adalah perspektif bisnis/ internal, dan Business Goalyang digunakan adalah Business Goal 15 yaitu improve and maintain operational and staff productivity [3].

Berdasarkan seluruh penuturan pada latar belakang ini, maka dilakukan penelitian, yaitu "Analisis Layanan dan Produktivitas Sumber daya manusia dengan Business Goal 15 Mengunakan COBIT 4.1 pada Diskominfo Provinsi Jawa Timur" menggunakan maturiy level dengan fokus Business Goal 15 pada framework COBIT 4.1, untuk mengidentifikasi, menganalisis, memberikan suatu penilaian, serta memberikan rekomendasi-rekomendasi untuk kinerja internal terkait peningkatan layanan dan produktivitas sumber daya manusia khususnya pada bidang yang mengampu implementasi TI terhadap proses bisnis, aplikasi atau penerapan TI, dan strategi bisnis perusahaan.

\section{Metode Penelitian}

Metode seperti Gambar 1 berikut, mengadopsi dan memadukan metode secara umum, Certified Information System Auditor (CISA) [6] dan COBIT 4.1 [3]. 


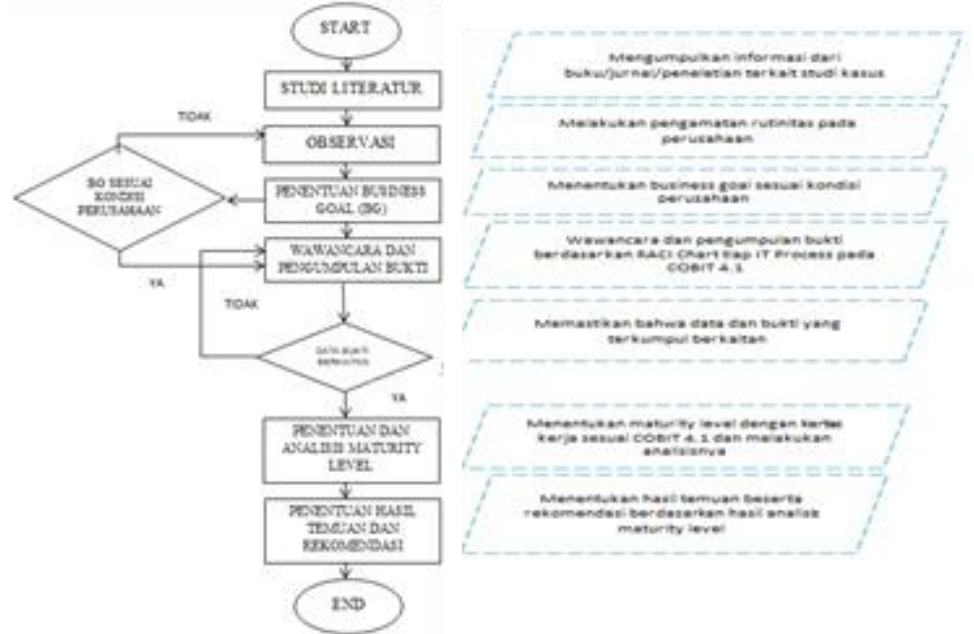

Gambar 1. Alur Metedologi Penelitian

\subsection{Tinjauan Pustaka}

\subsubsection{Gambaran Umum Perusahaan}

Diskominfo Provinsi Jawa Timur merupakan unsur dari pelaksana otonomi daerah yang dipimpin oleh kepala dinas, berada di bawah dan memiliki tanggung jawab Gubernur Jawa Timur melalui sekertaris daerah. Diskominfo Provinsi Jawa Timur memiliki tugas untuk menyiapkan bahan yang diperlukan dalam urusan pemerintahan pada bidang komunikasi dan informasi dalam lingkup Jawa Timur [2].

\subsubsection{Operasional dan Layanan}

Menurut Peni R Pramono (2007), Operasional adalah suatu kegiatan bisnis yang merupakan aktivitas utama di dalam perusahaan dengan memperhitungkan hasil pengadaan barang atau jasa [7]. Sedangkan layanan/pelayanan memiliki arti sama menurut Kamus Besar Bahasa Indonesia, yaitu sebuah perihal atau cara melayani atau melaksanakan sesuatu. Berdasarkan Keputusan Aparatur Negara No. 63 tahun disebutkan, pelayanan barang dan pelayanan jasa merupakan kelompok pelayanan yang ada di dalam keputusan tersebut [8]. Sehingga dapat disimpulkan bahwa operasional dan layanan memiliki keterkaitan, yaitu layanan merupakan salah bentuk dari suatu operasional, sebagai bentuk/cara melaksanakan sesuatu dalam kegiatan bisnis mengenai barang atau jasa.

\subsubsection{Produktivitas Sumber Daya Manusia}

Produktivitas menurut Ardana (2012) adalah perbandingan efektivitas yang menghasilkan keluaran (output) dengan efisiensi penggunaan sumber-sumber masukan (input). Menurut Priyono (2008), sumber daya manusia adalah kemampuan terpadu dari daya pikir dan daya fisik yang dimiliki individu. Perilaku dan sifatnya ditentukan oleh keturunan dan lingkungannya [9]. Sumber daya manusia merupakan faktor penting dalam perusahaan atau organisasi, yaitu sebagai alat penggerak operasional suatu usaha dengan seluruh fasilitas yang tersedia dalam pencapaian tujuan yang telah ditentukan. Sehingga dapat disimpulkan bahwa Produktivitas Sumber Daya Manusia yaitu perbandingan antara hasil yang dicapai dengan peran dan kemampuan terpadu dari daya pikir dan daya fisik yang dimiliki oleh tenaga kerja pada suatu perusahaan.

\subsubsection{COBIT 4.1}

Control Objectives for Information and related Technology (COBIT) dikenalkan sebagai kerangka kerja untuk mengelola IT Governance oleh Information System Audit and Control Association (ISACA). COBIT 4.1 memiliki keunggulan meliputi, penyelarasan yang lebih baik antara proses bisnis dengan IT, berdasarkan pada fokus bisnis, pandangan yang dapat dimengerti manajemen tentang apa yang dikerjakan TI, dan kepemilikan dan tanggung jawab yang jelas, berdasarkan pada orientasi proses [5]. COBIT 4.1 terdapat empat domain yang berkaitan, daintaranya Plan And Organizer (PO) yaitu memberi arahan untuk pengiriman solusi (Al) dan pemberian layanan (DS), Acquire And Implement (Al) yaitu menyediakan solusi dan 
mengubahnya menjadi layanan, Delivery And Support (DS) yaitu menerima solusi dan menjadikannya dapat digunakan oleh pengguna akhir (end use), Monitor and Evaluate (ME) yaitu memonitor seluruh proses guna memastikan arahan yang diberikan diikuti [3]. Dalam empat domain tersebut terdapat 34 IT Process.

\subsubsection{Maturity Level}

COBIT 4.1 menyediakan kerangka untuk mengidentifikasi sejauh mana perusahaan memenuhi standar dari pengelolaan penerapan TI berdasarkan tingkat kematangan atau maturity level. Kategori untuk mengukur kemampuan perusahaan dalam pengelolaan $\mathrm{TI}$, yaitu dari level 0 hingga 5 [3]. Tabel 1 berikut menunjukkan kondisi setiap level.

Tabel 1. Maturity Level

\begin{tabular}{|c|c|}
\hline Level & Penjelasan \\
\hline $\begin{array}{l}\text { Level } 0 \\
\text { Non-Existent }\end{array}$ & $\begin{array}{l}\text { ndisi dimana perusahaan belum menyadari kebutuhan akan Teknologi Informasi, } \\
\text { an bahkan belum mengakui bahwa ada masalah yang harus diatasi untuk } \\
\text { eningkatkan layanan dalam perusahaan. }\end{array}$ \\
\hline $\begin{array}{l}\text { Level } 1 \\
\text { Initial / Ad } \\
\quad \text { Hoc }\end{array}$ & $\begin{array}{l}\text { ondisi dimana perusahaan telah mengakui bahwa TI diperlukan, bahkan terdapat } \\
\text { ukti. Namun, tidak ada standar yang jelas dan manajemen tidak terorganisir, } \\
\text { arena kesadaran masih bergantung pada individu, bukan perusahaan. }\end{array}$ \\
\hline $\begin{array}{l}\text { Level } 2 \\
\text { Repeatable } \\
\text { and Intuitive }\end{array}$ & $\begin{array}{l}\text { Kondisi dimana ada tanggung jawab dan penanggung jawab TI. Namun, proses } \\
\text { masih bergantung kepada pengetahuan individu atau pihak tertentu, manajemen } \\
\text { tersebut otoritasnya terbatas, sehingga kesalahan mungkin terjadi. }\end{array}$ \\
\hline $\begin{array}{l}\text { Level } 3 \\
\text { Defined }\end{array}$ & $\begin{array}{l}\text { Kondisi dimana kebijakan atau prosedur perusahaan mengenai } \mathrm{TI} \text { telah } \\
\text { didefinisikan dan distandarisasi oleh manajemen perusahaan, bahkan pengujian } \\
\text { dan pelatihan TI telah dilaksanakan. Namun prosedur formal ada namun belum } \\
\text { canggih, sehingga kekurangan belum diatasi secara keseluruhan. Otomatisasi dan } \\
\text { peralatan yang digunakan masih terbatas. }\end{array}$ \\
\hline $\begin{array}{l}\text { Level } 4 \\
\text { Managed } \\
\quad \text { and } \\
\text { Measurable }\end{array}$ & $\begin{array}{l}\text { ondisi dimana mengenai TI telah diukur dan dipantau oleh manajemen. Analisis } \\
\text { iko atau jika terjadi kekurangan, dapat diperbaiki secara konstan. }\end{array}$ \\
\hline $\begin{array}{l}\text { Level } 5 \\
\text { Optimised } \\
\text { Level }\end{array}$ & $\begin{array}{l}\text { Kondisi dimana penerapan Teknologi Informasi merupakan tanggung jawab } \\
\text { bersama dari manajemen bisnis dan TI yang terintegrasi dengan tujuan bisnis } \\
\text { keamanan pada perusahaan. Proses telah disempurnakan berdasarkan perbaikan } \\
\text { dan perbandingan maturity level perusahaan lain. TI digunakan dengan baik untuk } \\
\text { mengotomatisasi alur kerja, menyediakan alat untuk meningkatkan kualitas dan } \\
\text { efektivitas, serta menjadikan perusahaan cepat beradaptasi. }\end{array}$ \\
\hline
\end{tabular}

Berdasarkan COBIT 4.1, Business Goal 15 memiliki empat IT Goals, yang di dalamnya ada IT Process, didefinisikan pada Gambar 2.

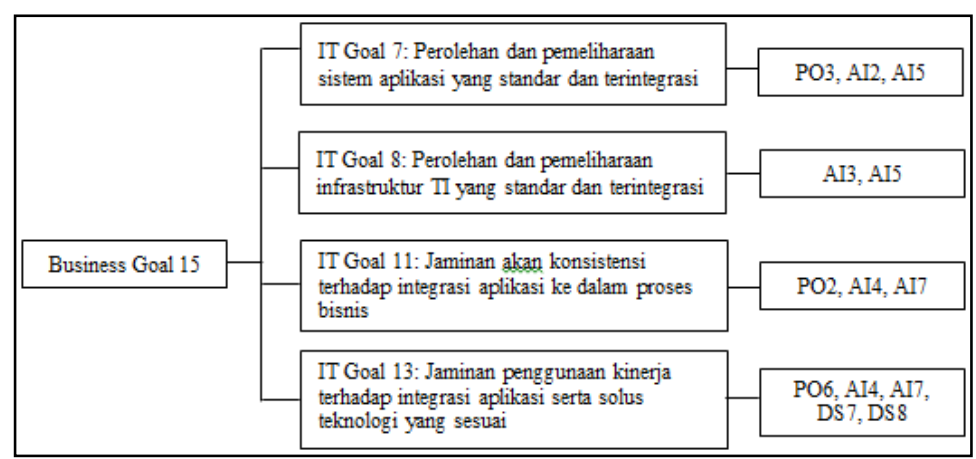

Gambar 2. Hubungan Business Goal 15 dengan IT Goal

Setelah mengetahui pemetaan Business Goal, IT Goal, dan IT Processnya, maka dapat dihitung berdasarkan Gambar 4, penentuan maturity level dilakukan dengan menggunakan kertas kerja yang berpedoman pada COBIT 4.1.

REPOSITOR, Vol. 2, No. 5, Mei 2020: 667-674 


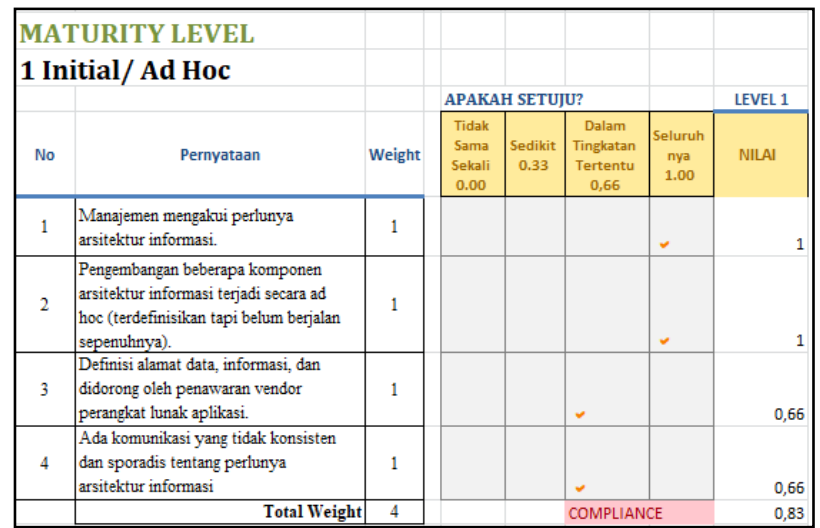

Gambar 3. Contoh Kertas Kerja Maturity Level [3] (IT Process PO2)

Seperti Gambar 3, setiap halaman kertas kerja terdapat satu IT Process yang terdiri dari lima level, dimana akan ada informasi terkait nama dan penjelasan terkait suatu IT Process, weight yaitu bobot untuk setiap satu pernyataan dalam setiap level pada IT Process, total weight yaitu jumlah total dari weight atau pernyataan pada setiap level. Satu pernyataan dibobotkan secara merata, yaitu 1.

Untuk melakukan penilaian pernyataan nilai kepatuhan (statement compliance value) ada empat kriteria nilai, yaitu tidak sama sekali bernilai 0 , sedikit bernilai 0,33 , dalam tingkatan tertentu bernilai 0,66, dan seluruhnya bernilai 1 [10]. Berdasarkan Gambar 3 dengan menggunakan contoh Level 1 pada IT Process $\mathrm{PO}$, perolehan nilai compliance, yaitu rata-rata nilai pada setiap level. Nilai compliance diperoleh dengan Persamaan 1.

$$
\frac{\text { Jumlah Value dalam Level }}{\text { Total Bobot }}
$$

\begin{tabular}{|c|c|c|c|}
\hline \\
\hline \multicolumn{4}{|c|}{$\begin{array}{l}\text { PERHITUNGAN LEVEL 0-5 (PO2) } \\
\text { LEVEL COMPLIANCE NORMALISE CONRIBUTIO }\end{array}$} \\
\hline 0 & 1 & 0 & 0 \\
\hline 1 & 0,83 & 0,333333333 & 0,276666667 \\
\hline 2 & 73333 & 0,666666 & 515555556 \\
\hline 3 & 16666 & 1 &, 716666667 \\
\hline 4 & 0,6255555 & 1,333333333 & 0,834074074 \\
\hline 5 & 0,612857143 & 1,666666667 & 1,021428571 \\
\hline sum & 4,558412698 & Matu & 3,364391534 \\
\hline
\end{tabular}

Dilakukan berulang pada seluruh level (0 hingga 5).

Seperti Gambar 4, setelah menemukan hasil nilai compliance, maka untuk mendapatkan nilai maturity level pada suatu IT Process, perlu menemukan hasil contribution [10]. Menurut Riyanarto Sarno (2009), contribution memberikan gambaran mengenai seberapa besar pengaruh compliance pada setiap level terhadap maturity suatu IT Process secara menyeluruh [3].

Sebelum menghitung Contribution, compliance harus dinormalisasi (normalise) untuk menyesuaikan perhitungan dengan Persamaan 2.

$$
\frac{\text { Level } n}{\text { Jumlah level } n} \times \text { Nilai maksimal level } n
$$

Artinya jumlah level $\mathrm{n}$ sama dengan 15 diperoleh dari penjumlahan level 0 hingga 5 , yang dimaksud dengan nilai maksimal level $\mathrm{n}$ adalah 5 . Setelah melakukan normalisasi, perhitungan contribution dengan rumus compliance $\times$ normalise. Maturity level diperoleh dari menjumlahkan contribution dari level 0-5. 


\section{Hasil Penelitian dan Pembahasan}

Bab ini menjelaskan proses analisis, hasil temua, dan rekomendasi dari penelitian yang telah dilakukan.

\subsection{Pemetaan RACI Chart pada Diskominfo Provinsi Jawa Timur}

Framework COBIT 4.1. menyediakan matriks Responsible, Accountable, Consulted and Informed (RACl) Chart sebagai kunci efektifitas pengendalian untuk memahami aturan dan tanggung jawab untuk setiap proses bisnis [5].

Struktur fungsional organisasi dipetakan dengan struktur fungsional yang telah disediakan oleh COBIT. Pemetaan dilakukan untuk menentukan narasumber yang akan diwawancarai pada Diskominfo Provinsi Jawa Timur, dimana setiap IT Process yang terdapat pada Business Goal 15 pada penelitian ini memiliki RACI Chart yang berbeda. Menurut Rofiuddin (2012), Responsible memiliki peran menjalankan dan bertanggung jawab secara langsung di lapangan sehingga dapat dikatakan bahwa fungsional yang memiliki peran Responsible tersebut yang akan menjadi sumber informasi dan data paling banyak dan akurat [11]. Berikut pada Tabel 2 akan menjelaskan pemetaannya.

Tabel 2. Pemetaan Fungsional RACI Chart (Responsible), Fungsional Diskominfo Provinsi Jawa Timur, dan IT Process

\begin{tabular}{|c|c|c|}
\hline Responsible & Fungsional Diskominfo & IT Process \\
\hline Chief Architect & Kepala Diskominfo Provinsi Jawa Timur & $\mathrm{PO} 2, \mathrm{PO} 3, \mathrm{Al} 3, \mathrm{DS} 8$ \\
\hline $\begin{array}{c}\text { Head } \\
\text { Development }\end{array}$ & $\begin{array}{l}\text { Kepala Bidang Aplikasi dan Informatika } \\
\text { Diskominfo Provinsi Jawa Timur }\end{array}$ & $\begin{array}{l}\text { PO2, Al2, Al3, Al4, Al5, } \\
\text { Al7, DS8 }\end{array}$ \\
\hline $\begin{array}{l}\text { Compliance, } \\
\text { Audit, Risk, and } \\
\text { Security }\end{array}$ & $\begin{array}{l}\text { Kepala Seksi Persandian dan Keamanan } \\
\text { Diskominfo Provinsi Jawa Timur }\end{array}$ & $\mathrm{PO} 2, \mathrm{Al} 2$ \\
\hline $\begin{array}{c}\text { Head IT } \\
\text { Administration }\end{array}$ & $\begin{array}{lll}\text { Kepala Seksi } & \text { Pengembangan } & \text { Aplikasi } \\
\text { Diskominfo Provinsi Jawa Timur } & \\
\end{array}$ & $\mathrm{PO6}, \mathrm{Al} 3, \mathrm{Al} 5$ \\
\hline $\begin{array}{l}\text { Project Manager } \\
\text { Owner }\end{array}$ & Kepala Bidang Aplikasi Informatika & Al2, Al5 \\
\hline $\begin{array}{c}\text { Business } \\
\text { Process Owner }\end{array}$ & Kepala Diskominfo Provinsi Jawa Timur & $\mathrm{Al} 2, \mathrm{Al} 4, \mathrm{Al} 7, \mathrm{DS} 7$ \\
\hline Head Operations & $\begin{array}{l}\text { Kepala Bidang Aplikasi dan Informatika, Kepala } \\
\text { Bidang Infrastruktur TIK, Kepala Bidang } \\
\text { Pengelolaan Data dan Statistik }\end{array}$ & $A I 3, A I 4, A I 5, A I 7, D S 8$ \\
\hline $\mathrm{ClO}$ & Kepala Diskominfo Provinsi Jawa Timur & PO6, Al7, DS7 \\
\hline CEO & Gubernur Jawa Timur & Al5 \\
\hline $\begin{array}{l}\text { Training } \\
\text { Department }\end{array}$ & $\begin{array}{lll}\text { Seksi Tata Kelola dan Pemberdayaan } & \text { TIK } \\
\text { Diskominfo Provinsi Jawa Timur } & \\
\end{array}$ & Al4, DS7 \\
\hline $\begin{array}{l}\text { Service } \\
\text { Desk/Incident } \\
\text { Manager }\end{array}$ & $\begin{array}{l}\text { Seksi Tata Kelola dan Pemberdayaan TIK } \\
\text { Diskominfo Provinsi Jawa Timur }\end{array}$ & DS8 \\
\hline $\begin{array}{l}\text { Deployment } \\
\text { Team }\end{array}$ & $\begin{array}{l}\text { Al4 Seksi Tata Kelola dan Pemberdayaan TIK } \\
\text { Diskominfo Provinsi Jawa Timur }\end{array}$ & Al4 \\
\hline
\end{tabular}

\subsection{Hasil Penentuan dan Analisis Maturity Level}

Berikut merupakan hasil maturity level seluruh IT Process berdasarkan Business Goal 15 COBIT 4.1 pada Diskominfo Provinsi Jawa Timur, dijelaskan dalam Tabel 3.

Tabel 3. Hasil Maturity Level Seluruh IT Process Business Goal 15

\begin{tabular}{|c|c|c|c|}
\hline Domain & $\begin{array}{c}I T \\
\text { Process }\end{array}$ & Maturity Level & $\begin{array}{c}\text { Rata-Rata Maturity } \\
\text { Level }\end{array}$ \\
\hline \multirow{3}{*}{ Plan and Organise (PO) } & PO2 & 3,364391534 & \multirow{3}{*}{ 3,173207231 } \\
\hline & $\mathrm{PO} 3$ & 3,064952381 & \\
\hline & PO6 & 3,090277778 & \\
\hline \multirow{2}{*}{ Acquire and Implement (Al) } & Al2 & 3,038777778 & \multirow{2}{*}{3,024554762} \\
\hline & $\mathrm{Al} 3$ & 3,291166667 & \\
\hline
\end{tabular}

REPOSITOR, Vol. 2, No. 5, Mei 2020: 667-674 


\begin{tabular}{cccc} 
& Al4 & 3.039972222 & \\
\cline { 2 - 3 } & Al5 & 3,03952381 & \\
\cline { 2 - 3 } Deliver and Support (DS) & Al7 & 2,713333333 & \\
\cline { 2 - 3 } & DS7 & 3,045714286 & \multirow{2}{*}{2,706190476} \\
\hline \multicolumn{2}{c}{ Rata-rata maturity level seluruh domain } & DS8 & 3,005477646
\end{tabular}

Berdasarkan Tabel 3, hasil pengukuran maturity level berdasarkan Business Goal 15 COBIT 4.1, Diskominfo Provinsi Jawa Timur memperoleh maturity level sebesar 3,005477646. Angka tersebut menjelaskan bahwa tingkat layanan dan produktivitas sumber daya manusia terkait implementasi TI pada Diskominfo Provinsi Jawa Timur mencapai level, yaitu defined. Kondisi defined pada COBIT 4.1 mendefinisikan bahwa Diskominfo Provinsi Jawa Timur memiliki kebijakan terkait standarisasi dan dokumentasi yang dipahami dan disepakati oleh seluruh tingkatan pada perusahaan. Adanya kekurangan mengenai layanan dan produktivitas sumber daya manusia terkait implementasi TI dapat teridentifikasi, dan ditemukan solusi untuk penyelesaiannya, meskipun belum secara keseluruhan karena beberapa prosedur bersifat informal, seperti arsitektur informasi, infrastruktur TI, pelatihan dan pendidikan pengguna, serta manajemen layanan/insiden.

\subsection{Penentuan Hasil Temuan dan Rekomendasi}

Tabel 4 berikut merupakan beberapa contoh hasil temuan dan rekomendasi tiap domain pada Diskominfo Provinsi Jawa Timur berdasarkan dengan COBIT.

Tabel 4. Hasil Temuan dan Rekomendasi

\begin{tabular}{|c|c|c|}
\hline Domain & Hasil Temuan & Hasil Rekomendasi \\
\hline $\begin{array}{l}\text { Plan and } \\
\text { Organise }\end{array}$ & $\begin{array}{l}\text { Pengembangan beberapa komponen } \\
\text { arsitektur informasi terjadi secara ad } \\
\text { hoc atau belum secara keseluruhan } \\
\text { dijalankan. }\end{array}$ & $\begin{array}{l}\text { Untuk mendukung pengembangan } \\
\text { arsitektur informasi sebaiknya } \\
\text { perlu kebijakan terkait metode dan } \\
\text { teknik formal }\end{array}$ \\
\hline $\begin{array}{l}\text { Aqcuire } \\
\text { and } \\
\text { Implement }\end{array}$ & $\begin{array}{l}\text { Belum ada kerangka kerja yang } \\
\text { ditetapkan untuk memelihara prosedur } \\
\text { dan materi pelatihan. }\end{array}$ & $\begin{array}{l}\text { Sebaiknya kerangka kerja dibuat } \\
\text { untuk memelihara prosedur dan } \\
\text { manual pelatihan yang mencakupi } \\
\text { semua sistem dan unit bisnis. }\end{array}$ \\
\hline $\begin{array}{l}\text { Deliver } \\
\text { and } \\
\text { Support }\end{array}$ & $\begin{array}{l}\text { Belum ada prosedur untuk menangani } \\
\text { terkait keseluruhan layanan dan } \\
\text { insiden. }\end{array}$ & $\begin{array}{l}\text { Sebaiknya perlu membuat proses } \\
\text { dan prosedur standar terkait } \\
\text { proses manajemen insiden dan } \\
\text { fungsi meja layanan secara formal. }\end{array}$ \\
\hline
\end{tabular}

\section{Kesimpulan}

Berdasarkan uraian metode penelitian yang menjelaskan mengenai hasil pengukuran maturity level berdasarkan Business Goal 15 COBIT 4.1, Diskominfo Provinsi Jawa Timur memperoleh maturity level sebesar 3,005477646.

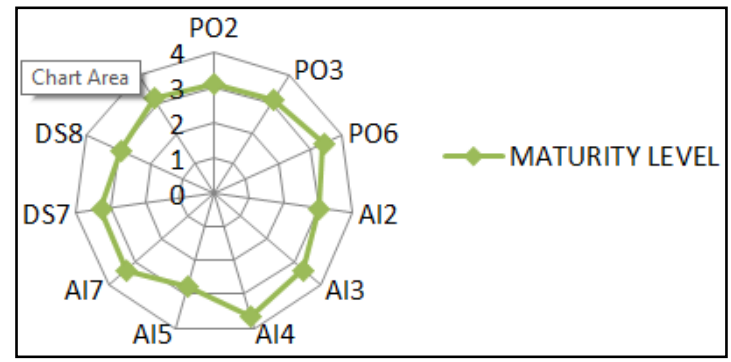

Gambar 5. Maturity Level seluruh IT Process pada Business Goal 15

Gambar 5 menggambarkan hasil maturity level penelitian ini di seluruh IT Process pada Business Goal 15. Angka tersebut menjelaskan bahwa tingkat layanan dan produktivitas sumber daya manusia terkait implementasi TI pada Diskominfo Provinsi Jawa Timur mencapai level, yaitu defined. Kondisi defined pada COBIT 4.1 mendefinisikan bahwa Diskominfo Provinsi Jawa Timur 
memiliki kebijakan terkait standarisasi dan dokumentasi yang dipahami dan disepakati oleh seluruh tingkatan pada perusahaan. Adanya kekurangan mengenai layanan dan produktivitas sumber daya manusia terkait implementasi TI dapat teridentifikasi, dan ditemukan solusi untuk penyelesaiannya, meskipun belum secara keseluruhan karena beberapa prosedur bersifat informal.

\subsection{Saran}

Penelitian selanjutnya diharapkan dapat menggunakan Business Goal yang berbeda perspektif berdasarkan COBIT 4.1 pada Diskominfo Provinsi Jawa Timur, maka akan diperoleh lebih banyak IT Process untuk menjadi bahan dalam memperoleh narasumber, sehingga perolehan hasil penelitian bisa lebih maksimal lagi. Penelitian selajutnya diharapkan dapat membuat timeline yang lebih terstruktur dalam melakukan wawancara dan pengumpulan bukti, sehingga dapat diikuti dan memperoleh hasil maksimal.

\section{Referensi}

[1] Timur, P.G.J, 2016. Peraturan Gubernur Nomor 80 Tahun 2016 tentang Kedudukan, Susunan Organisasi, Uraian Tugas dan fungsi Serta Tata Kerja Dinas Komunikasi dan Informatika Provinsi Jawa Timur. Pp. 1-20.

[2] Pratama, A., 2019. Jurnal SIBC. Perencanaan Sistem Informasi Bidang Aptika Dinas Komunikasi dan Informatika Provinsi Jawa Timur. 12, pp. 23-32

[3] Sarno, Riyanarto., 2000. Audit Sistem Informasi \& Teknologi Informasi. Surabaya: ITS Press.

[4] Stroud, R. E., 2012. Comparing Cobit 4.1 and Cobit 5. http://www.isaca.org/COBIT/Documents/Comparing-COBIT.pdf [Accessed 14 Januari 2020]

[5] ITGI. COBIT 4.1; Framework, Control Objectives Management Guideline. 2007. United States of America. ITGI

[6] ISACA.,. CISA. 2019. CISA Review Manual 27th Edition. 27 th Edition. USA. ISACA.

[7] Riyanto, T. A., 2019. The Importance of Supervision and Distribution of Work Volume to Office Operations. https://www.academia.edu/39781504/Pengtingnya_Pengawasan_dan_Pembagian_Volum e_Kerja_Terhadap_Operasional_Kantor?auto=download. [Accessed 28 Desember 2019]

[8] Hasnih., 2016. Pengaruh Lima Dimensi Kualitas Pelayanan Publik Terhadap Tingkat Kepuasan Masyarakat Di Kelurahan Ompo Kecamatan Lalabata Kabupaten Soppeng. Jurnal Mirai Management. Vol 1, pp. 426-445.

[9] Priyono., 2008. Manajemen Sumber Daya Manusia. Sidoarjo. Zifatama Publisher.

[10] Pederiva, A., 2013. The COBIT Maturity Model in a Vendor Evaluation Case. Information System Control Journal. 3.

[11] Kusumastuti, Nabila D., 2017. Analisis Tingkat Kematangan Berdasarkan Perspektif Internal Tujuan Bisnis 14 Menggunakan Standar COBIT 4.1 (Studi Kasus: PT. Kai Daop 8 Surabaya). Jurnal SIBC. Pp. 35-45. 